\title{
Scholars and Literati at the University of Bologna $(1088-1800)$
}

\author{
David de la Croix Mara Vitale \\ IRES/LIDAM, UCLouvain
}

This note is a summary description of the set of scholars and literati who taught at the University of Bologna from its inception in the 11th century to the eve of the Industrial Revolution (1800).

\section{The UnIVERSiTy}

The University of Bologna is one of the oldest academic institutions in the Western World and the first to use the term universitas to define a community of students and masters. Founded in 1088 by an organised guild of students who chose and financed their teachers, the studium established its reputation as a place where research could be developed independently of religious and secular power (Rashdall 1895). Among the several studies devoted to the history of the University, the most important are the Sorbelli and Simeoni's "Storia dell'Università di Bologna" (1940), and the book "Alma Mater Studiorum. L'università di Bologna nella storia della cultura e della civiltà" by the historian Calcaterra (1948). Both these works retrace the main events and portray the most important figures of the history of the university, from its foundation to 1888 .

\section{SOURCES}

The book by Mazzetti (1847) is the largest and most complete compilation of professors and intellectuals who have taught at the University of Bologna from its foundation until the first half of the 19th century. The author traces short biographies, sorted in alphabetical order, enriched with anecdotes about the private and academic life of the professors. To complete the biographies provided in Mazzetti (1847), we have used the dictionaries by the Istituto dell'Enciclopedia Italiana (1929), (1961), and by Taisand (1721) for the lawyers.

\section{SOME STATISTICS}

Table 1 shows some descriptive statistics. There are 3270 scholars and literati. The year of birth is known for $17.8 \%$ of them. The mean age at appointment is 33.6 years, and this is quite stable over the periods. Longevity (mean age at death \& expected age at death when 30) is high during the first period, probably because of a selection effect (the footprint of those who died young has been lost). In accordance with the literature on the historical life expectancy of elites (Stelter, De la Croix, and Myrskylä 2021), longevity improves in the last two periods. The birth place is known for $91.8 \%$ of the people, thanks to the systematic registration of the place of origin in the records. The median distance between birth and Bologna is $0 \mathrm{~km}$, meaning that more than half of the scholars come from the city. There is more variety in origins for the first three periods though. Finally, $10 \%$ of the scholars have a Wikipedia page (in some language), and $14.9 \%$ of them have left a footprint in the catalogues of the libraries of the world, Worldcat, either by having published some work, or by having been the subject of published books and articles. 


\begin{tabular}{|c|c|c|c|c|c|c|}
\hline \multicolumn{2}{|c|}{ Period } & \multirow{2}{*}{$\begin{array}{l}\text { nb. } \\
\text { obs }\end{array}$} & \multirow{2}{*}{$\begin{array}{c}\text { \% birth year } \\
\text { known }\end{array}$} & \multirow{2}{*}{$\begin{array}{l}\text { mean age } \\
\text { at appoint. }\end{array}$} & \multirow{2}{*}{$\begin{array}{c}\text { mean age } \\
\text { at death }\end{array}$} & \multirow{2}{*}{$\begin{array}{l}\text { exp. age } \\
\text { at death }\end{array}$} \\
\hline Start & End & & & & & \\
\hline 1000 & 1199 & 102 & 19.6 & 32.1 & 68.1 & 70.8 \\
\hline 1200 & 1347 & 449 & 16.9 & 35.1 & 66.2 & 64.4 \\
\hline 1348 & 1449 & 808 & 9.8 & 33.7 & 65.5 & 65.3 \\
\hline 1450 & 1526 & 562 & 16.0 & 33.8 & 62.8 & 62.9 \\
\hline 1527 & 1617 & 439 & 23.2 & 35 & 63.8 & 63.5 \\
\hline 1618 & 1685 & 392 & 15.1 & 31.9 & 64.1 & 63.4 \\
\hline 1686 & 1733 & 216 & 25.5 & 32 & 71.0 & 69.9 \\
\hline 1734 & 1800 & 302 & 33.1 & 33.5 & 68.2 & 68.8 \\
\hline \multirow[t]{3}{*}{1000} & 1800 & 3270 & 17.8 & 33.6 & 65.8 & 65.9 \\
\hline & & & $\%$ birth place & median distance & $\%$ with & $\%$ with \\
\hline & & & known & birth-institution & Wikipedia & Worldcat \\
\hline 1000 & 1199 & & 71.6 & 73 & 30.4 & 29.4 \\
\hline 1200 & 1347 & & 88.2 & 73 & 17.1 & 20.9 \\
\hline 1348 & 1449 & & 91.5 & 49 & 5.4 & 8.0 \\
\hline 1450 & 1526 & & 92.2 & 0 & 9.1 & 14.7 \\
\hline 1527 & 1617 & & 97.7 & 0 & 11.6 & 21.0 \\
\hline 1618 & 1685 & & 92.1 & 0 & 6.1 & 11.2 \\
\hline 1686 & 1733 & & 94.9 & 0 & 8.8 & 14.8 \\
\hline 1734 & 1800 & & 93.0 & 0 & 9.6 & 15.2 \\
\hline 1000 & 1800 & & 91.8 & 0 & 10 & 14.9 \\
\hline
\end{tabular}

Table 1: Summary statistics by period

\section{FIELDS}

Figure 1 shows the relative importance of fields, broadly defined. The University is historically notable for its teaching of both canon and civil law. The teaching of theology was introduced only in 1360, by Innocent VI. Before this date, distinguished scholars were invited as lecturers. From the 14th century, the universitas artistarum was added, that is Medicine, Philosophy, Arithmetic, Astronomy, Logic, Rhetoric and Grammar (Bernabeo and D’Antuono 1988). In the 18th century, with the Industrial Revolution, the University promoted scientific and technological development.

\section{Place OF BIRTH}

Figure 2 is a plot of the places of birth of all the scholars of Bologna, and shows the European character of this university. Over the period 1200-1347, many professors were hired from North-West Europe. Several scholars came from modern-day Greece/Turkey before the end of the Byzantine Empire (1454). During the last period, Spain is an important contributor to the academic pool.

\section{HUMAN CAPITAL OF SCHOLARS AND LITERATI}

For each person in the database we compute a heuristic human capital index, identified by combining information from Worldcat and Wikipedia using a principal component analysis. We also compute the notability of the university at each date by averaging the human capital of the scholars active in Bologna 25 years before that date. Details are given in the Appendix. Figure 3 shows the names of all the scholars with a positive human capital index. The orange line plots the notability of the university. 


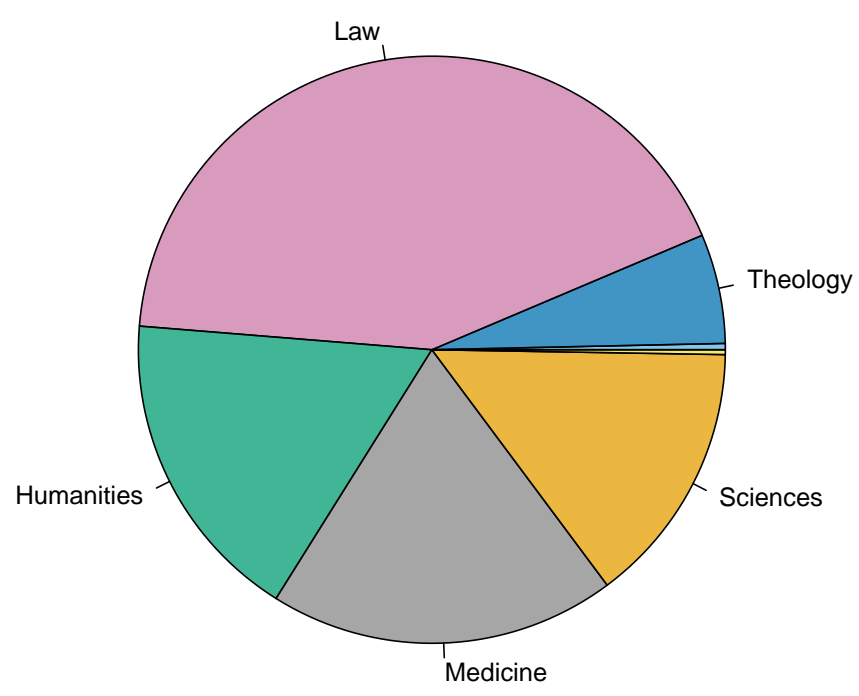

Figure 1: Broad fields at Bologna

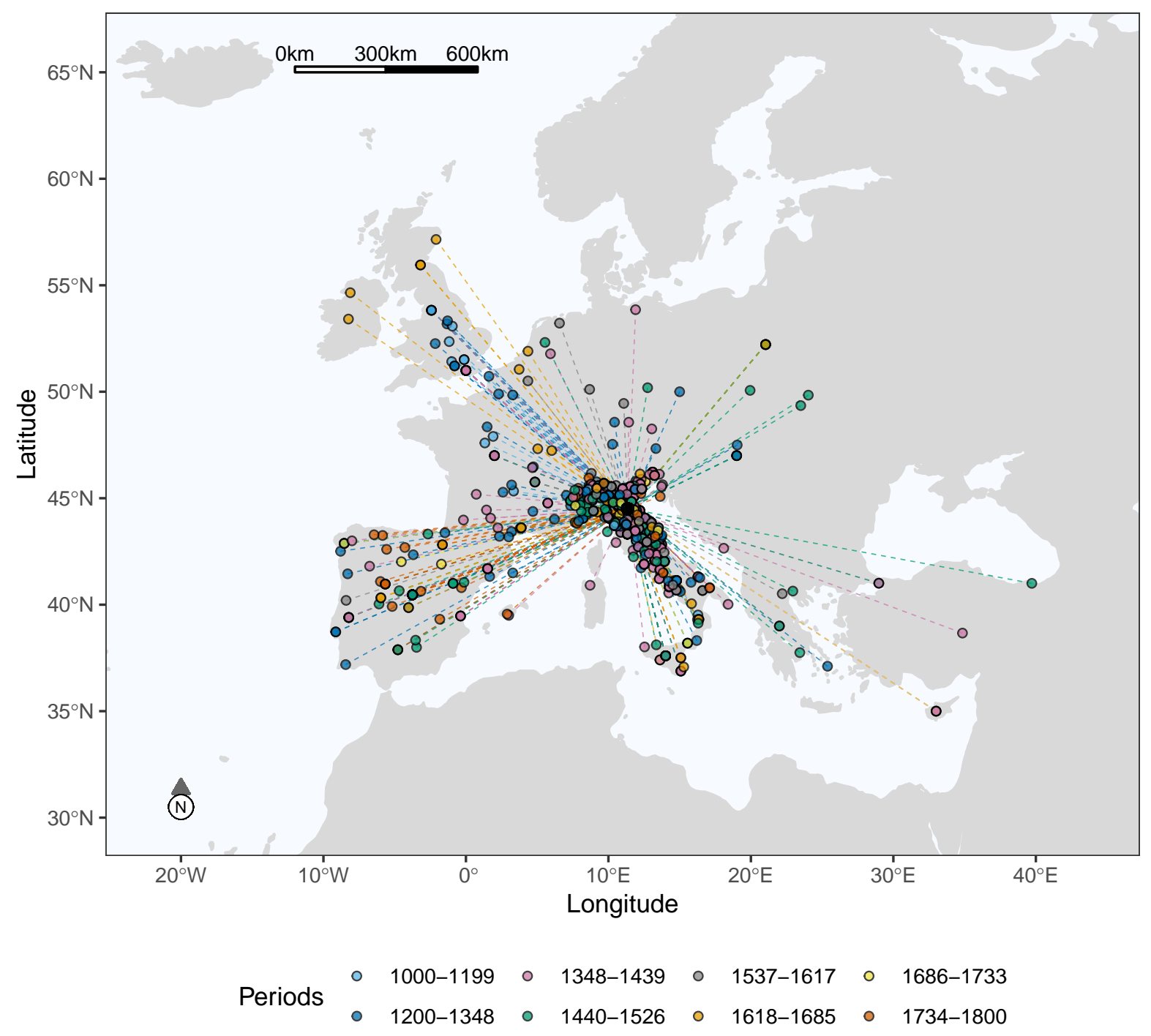

Figure 2: Place of birth of the scholars and literati at the University of Bologna 


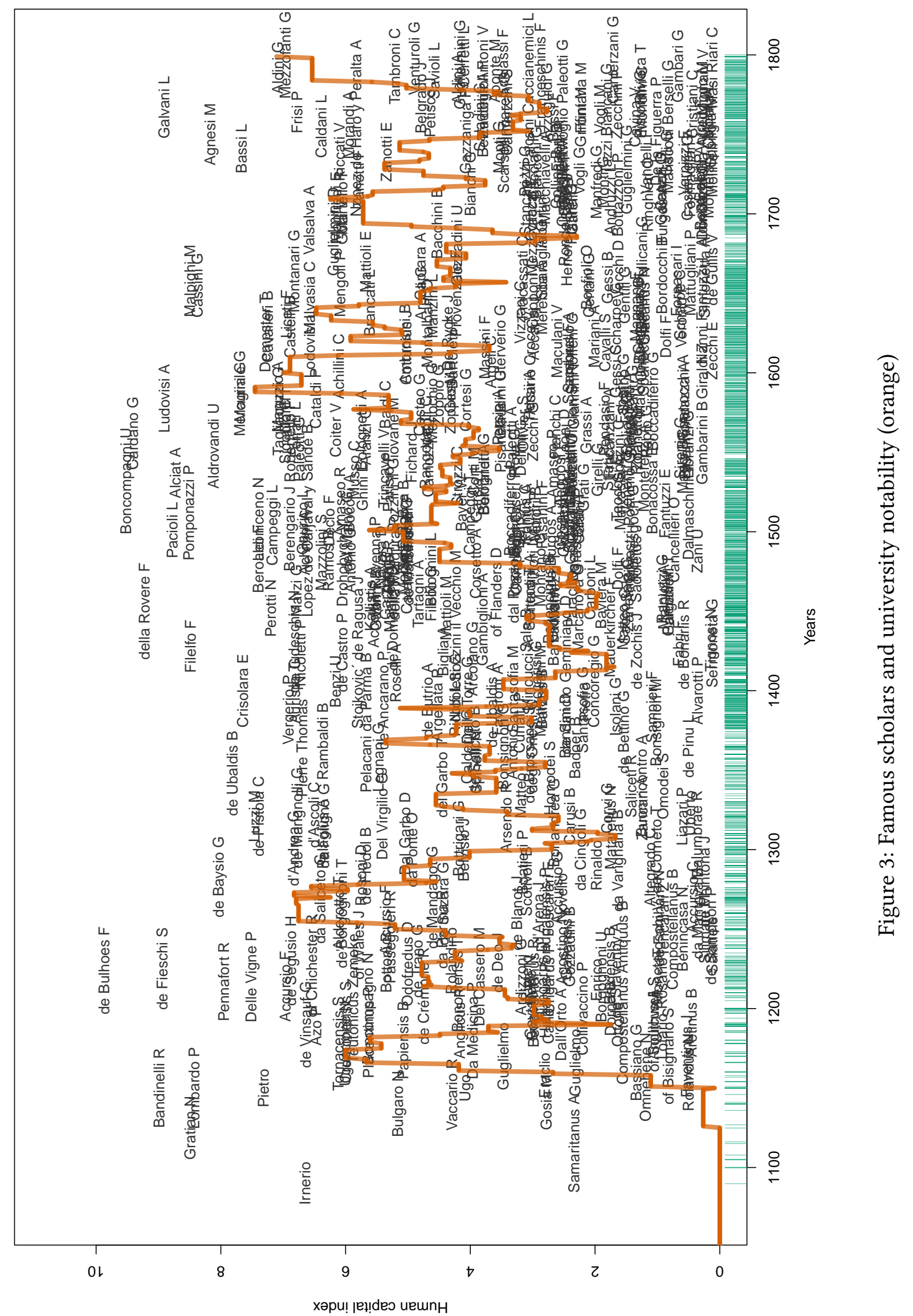


The pattern is one of high quality through time. Every period has some superstars, followed by a mass of scholars publishing very well. Notability peaks around 1250, and then in 1600 and 1800 . The period $1300-1500$ is the one with the lowest notability score. Finally, the vertical green lines (rug plot) show the distribution of all scholars, including the obscure ones, over time.

\section{TOP 10 PROFESSORS}

We now provide a brief overview of the ten professors with the highest human capital index.

Fernando Martins de Bulhões (Lisbon 1195 - Padua 1231), also known as St. Anthony of Padua, was a member of the Franciscan religious order. St. Francis entrusted him with the teaching of theology, to counter the heretical movements that were spreading in Europe in the 13th century. Mazzetti identifies him as a lector of theology in the studium. A year after his death he was canonized.

Giacomo Cardano (Pavia 1501 - Rome 1576), was a mathematician, physician and academic of great genius. He taught medicine at the universities of Pavia and Bologna. He was one of the most influential mathematicians of the Renaissance. He is remembered for the dispute with the mathematician Tartaglia, who plagiarized the resolution of the fourth-degree equation. He invented the combination lock and the gimbal joint.

Ugo Boncompagni (Bologna 1501 - Rome 1585) known as Pope Gregory XIII, before the tonsure he taught civil law at the University of Bologna. During his pontificate he worked to achieve the religious unity of the Christians of Europe through the reform of the Church. He is best known for commissioning the Gregorian calendar.

Francesco della Rovere (Pecorile 1414 - Rome 1484), in 1471 was appointed Pope of the Catholic Church and took the name Sixtus IV. He obtained a doctorate in theology in 1444, and spent his early academic career in several Italian universities. In Bologna he taught philosophy and theology. During the papacy, he was inspired by his love for art, erecting the Sistine Chapel and supporting important artists. He is also remembered for his nepotism, which led him to become involved in the Pazzi conspiracy.

Rolando Bandinelli (Siena c. 1100/1105 - Civita Castellana 1181), was professor of canon law in Bologna. After a period of teaching, he began a long and eventful ecclesiastical career in Rome. In 1159, he became pope with the name of Alexander III. He is remembered for his firm opposition to Emperor Frederick Barbarossa, and for the stance taken in the case of the assassination of Archbishop Thomas Becket. In fact, Alexander III forced the King of England to admit his connection with the murderers, o swear obedience to the Holy See, and repeal the laws against ecclesiastical freedoms.

Luigi Galvani (Bologna 1737 - Bologna 1798) taught anatomy and obstetrics at the University of Bologna from 1769 to 1797 , when he had to renounce his chair because he refused to swear allegiance to the Cisalpine Republic founded by Napoleon. He is widely recognized as a pioneer of bioelectromagnetics, the study of the interaction between electromagnetic fields and biological entities. His research led him to invent instruments that were subsequently named after him, like the galvanometer and the galvanizer.

Fieschi Sinibaldo (Manarola 1195 circa - Naples 1254) was a professor of canon law at the University of Bologna and became pope in 1241 as Innocent IV. His pontificate was notably marked by the struggle against Frederick II in the long quarrel between the Church and the Empire.

Alessandro Ludovisi (Bologna 1554 - Rome 1623) became a lecturer at Bologna immediately after his doctorate in utroque iure. This academic experience did not last long, as he soon took holy orders and began his ecclesiastical career. In 1621, he became Pope Gregory XV.

Luca Pacioli (Borgo Sansepolcro bef. 1445 - Rome 1517) was a Franciscan, mathematician, and economist. He was a lecturer of mathematics at several Italian universities, including Bologna. 
He collaborated with important figures of the Italian Renaissance, most notably Leonardo da Vinci. He is considered as the father of double-entry bookkeeping.

Andrea Alciati (Milano 1492 - Pavia 1550) was a jurist and professor at many Italian and French universities. He taught at Bologna for four years, where he championed a thoroughly humanistic approach to the study of law, which involved the knowledge of history and philology. He is considered as one of the most prominent French legal humanists.

\section{RELATED SCHOLARS}

Beyond those who taught at Bologna, several important individuals are related to the University. They probably did not occupy an official position, but they were involved in teaching and/or research. Here, we show here the three related scholars with the highest human capital index. Those scholars are counted to establish all figures but Figure 3 .

Thomas Becket (London 1117 - Canterbury 1170) was Archbishop of Canterbury. He opposed the restrictive policies over the rights and privileges of the Church put in place by Henry II, King of England. Forced into exile, he returned to his homeland only in 1170, when he was assassinated by the followers of the king. Mazzetti counts him among the professors of jus civilis at the University around the middle of the 12th century, while other sources identify him as a student. He was canonized in 1325 .

Domingo Guzman (Caleruega 1170 - Bologna 1221), was a Spanish priest who founded the Dominican Order in 1216 in Toulouse. The Order, fouded to counter the heretical movements of the time, expanded rapidly in various regions of Europe, particularly in the main university centers of the time, Paris and Bologna. Weakened by the numerous travels, penitences and restrictions that he imposed upon himself, he died in the convent of St. Nicholas in Bologna. He was canonized in 1234 .

Albertus Magnus (Lauingen bef. 1200 - Cologne 1280) was a Dominican friar and bishop of Regensburg. He taught theology at the universities of Paris and Cologne, with some appearances at Bologna and Würzburg. He distinguished himself for his works on philosophy, alchemy, astronomy and biology. Thomas Aquinas was one of his disciples. He was canonized and proclaimed doctor universalis by Pope Pius XI in 1931.

Giovanni Bessarione (Trebizond 1403- Ravenna 1472), whose true name was Basil, was a Roman Catholic bishop, who later became the Latin Patriarch of Constantinople. A theologist and humanist of great fame, in 1450 he was sent by the Pope in Bologna, where he had the mission to tame internal disorders. He used his power and influence to attract to Bologna the most important professors of the time.

\section{WHO'S WHO ON THE MOON}

Another way to measure the notability of individuals is to look for signs of recognition such as street names, ... and lunar crater names. The following nine professors received this honor (with first year at University of Bologna): Cecco d'Ascoli (1322), Gerolamo Cardano (1562), Giovanni D. Cassini (1650), Bonaventura Cavalieri (1629), Luigi Galvani (1763), Luca Gaurico (1506), Fortuno Liceti (1637), Giovanni A Magini (1588), and Geminiano Montanari (1664).

\section{Diversity}

Starting from the 13th century, women were admitted to teaching. In most cases, the first women in academia belonged to the Bolognese bourgeoisie and were hired to replace their fathers or husbands. Although they were limited in number, the presence of women in the history of the studium can be considered as an expression of the process of social change that has characterized Bologna since the foundation of its University. 


\section{Censorship}

Among the 312 scholars who have published some work after $1400 \mathrm{CE}, 15$ have been censored by the Catholic Church in its Index Librorum Prohibitorum (De Bujanda and Richter 2002). A rate of censorship of 5\% is about in line with Italy in general (Blasutto and De la Croix 2021). Famous examples are:

Luca Guarico (Giffoni 1475 - Rome 1558, censored in 1559) was a mathematician, astronomer, and astrologer. Also a Catholic bishop, he was the trusted astrologer of many famous people of the time, for to whom he successfully predicted the future. In Bologna he taught astronomy for a short period, until the Bentivoglio, ruler of Bologna, had him accused of heresy for having predicted his fall. His texts were then burned, and he was tortured using the mancuerda method.

Pietro Pomponazzi (Mantova 1462 - Bologna 1525, censored in 1596) was a professor of philosophy at the universities of Padua, Ferrara and Bologna. In 1514 he was accused of heresy by the Inquisition and his works were publicly burned in Venice. In his lectures Pomponazzi questioned the theories of Thomas Aquinas on the immortality of the soul, and invited his students to critically reconsider the role of Christianity in contemporary society.

Thomas Dempster (Cliftbog, Aberdeenshire 1579 - Bologna 1625, censored in 1617), was a professor of history and a prominent etruscologist. He taught in France and later moved to Italy where he was given a professorship first in Pisa and then in Bologna. Some of his works were put on the list of forbidden books, but only with the recommendation to correct some parts. A larger-than-life figure, Dempster died after learning of his wife's betrayal and affair with a student.

\section{FAMILIES OF SCHOLARS}

As in most Italian universities, the majority of professors were married laymen (Grendler 2002). Some had children who also appear as professors in the same university as their father. We counted 171 such father-son pairs. In many cases, the father is better known and has more publications than the son, which might indicate some degree of favoritism in the appointments (De la Croix and Goñi 2020). For example, Figure 4 shows the root of the genealogical tree of the Sampieri family, and highlights those who taught (law) at Bologna. Among the eight names, only Floriano has some publications in Worldcat.

\section{INTERSECTIONS WITH NEARBY UNIVERSITIES}

Among the 3270 Bolognese scholars, 3032 do not appear on university rolls in the nearby universities of Padua, Macerata, Pavia and Pisa. Hence 238 Bolognese scholars also occupied academic positions nearby. The Venn diagram shows that the intersection with the largest number of individuals is with the University of Padova.

\section{UNIVERSITY NETWORK}

Here we assume that when a professor occupied a position in more than one university over his/her life, this established a link between those universities. The universities with which Bologna is linked are displayed in Figure 6. We also observe here a shift towards Southern universities as time passes, witness to the barriers put in place by the Protestant Reformation and the Catholic Counter-Reformation (De la Croix and Morault 2020). 


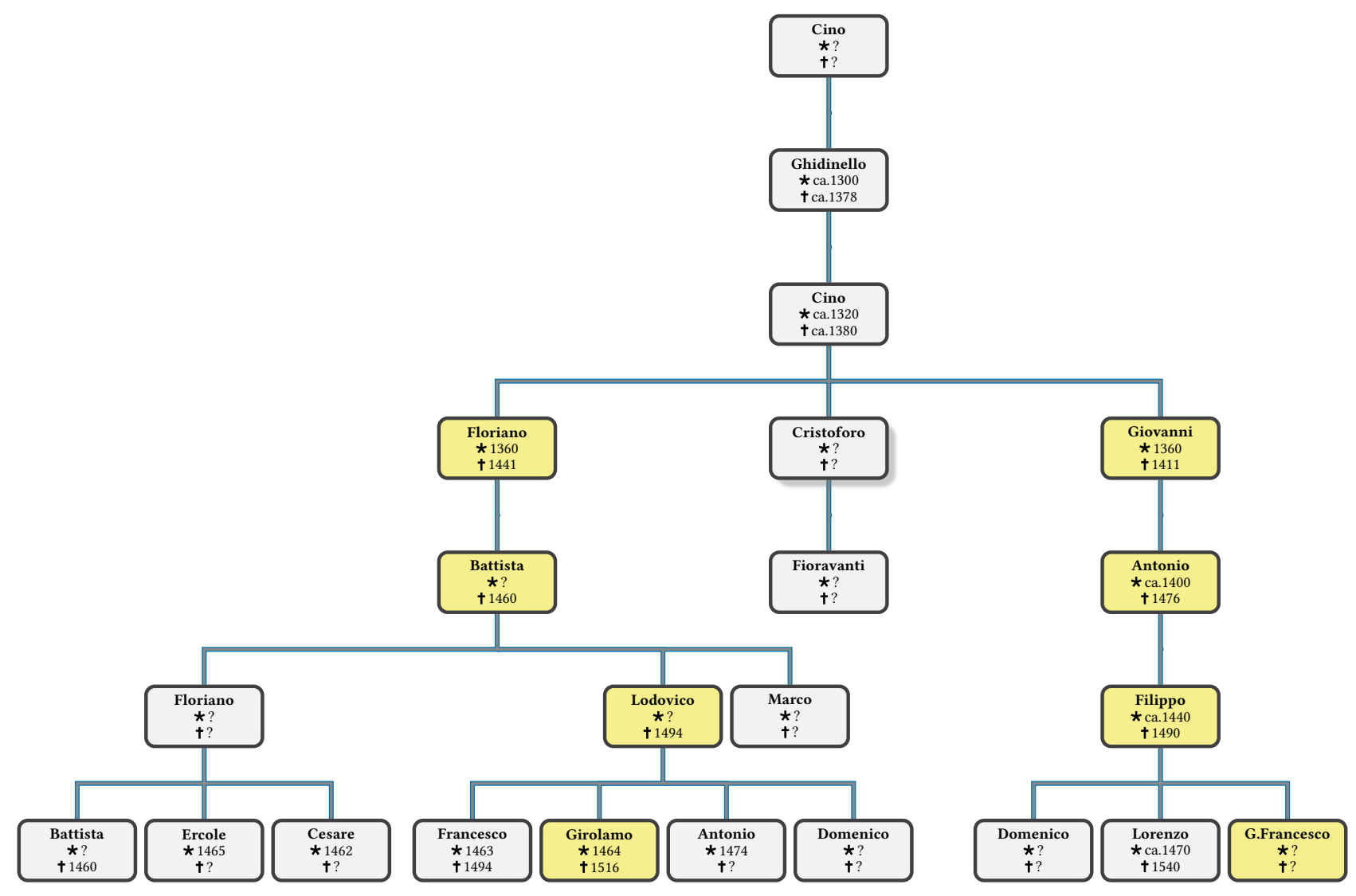

Figure 4: The Sampieri family. Professors at Bologna in yellow squares

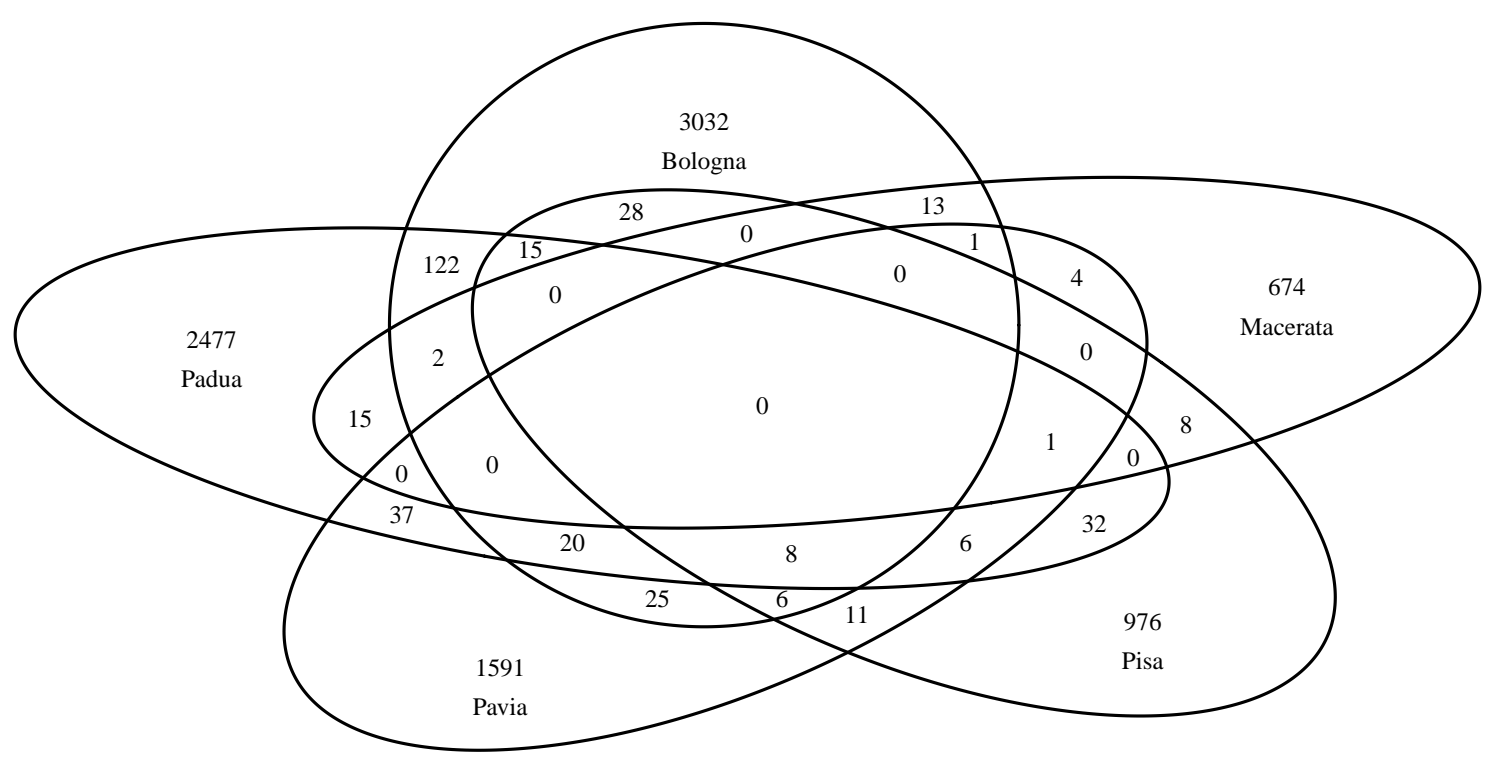

Figure 5: Intersections of the lists of scholars between the main universities of Northern Italy 


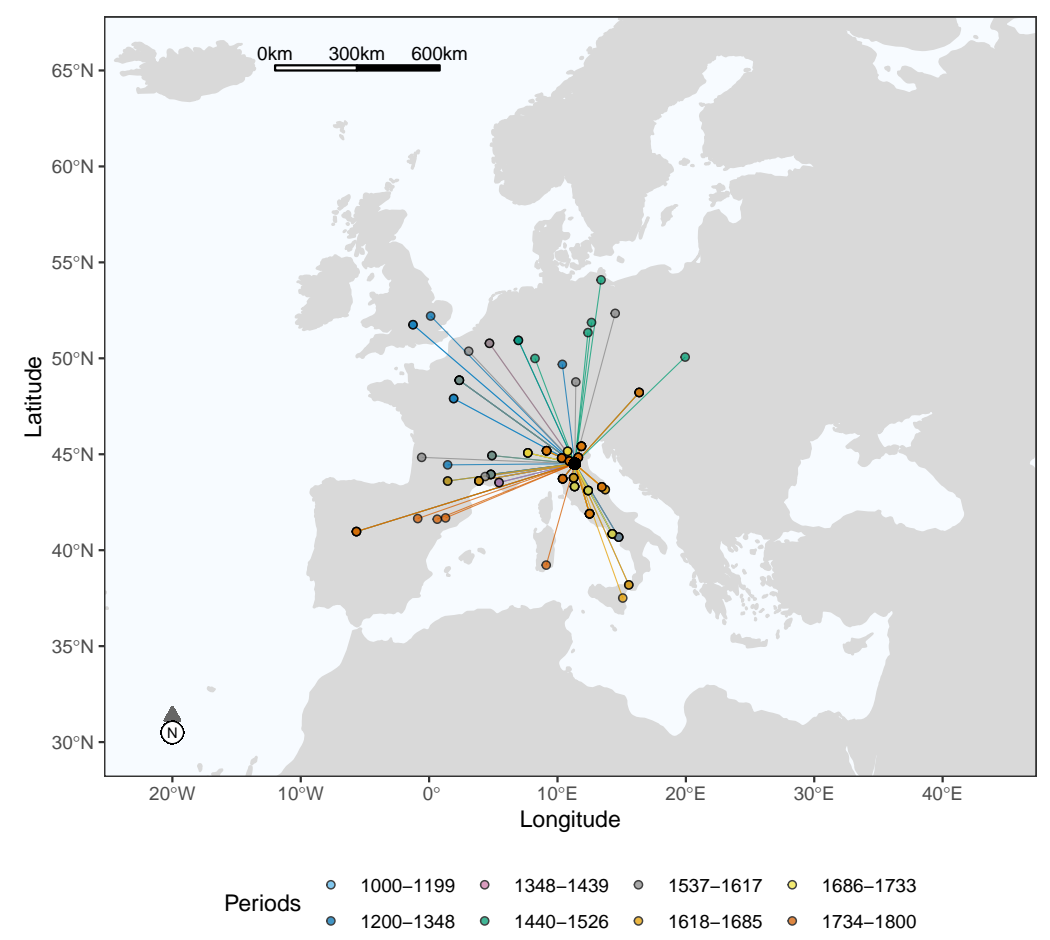

Figure 6: Links between Bologna and other universities through scholars' mobility, by period

\section{ANECDOTES}

The Protomedic Ulisse Aldrovandi modified Galen's formula to produce Theriac (an alexipharmic considered a panacea). The apothecaries criticized the quality of the vipers used for the concoction and sued him in court. The supreme court dismissed Aldrovandi from his office and he was expelled from the college for five years, until he was reinstated upon the intercession of Pope Gregory XIII (Cevoloni and Buscaroli 2018).

A law graduate, Novella Calderini on some occasions replaced her husband Giovanni da Legnano at the University of Bologna. Prudhomme (1830) reports that, in order not to distract the students with her extraordinary beauty, she gave her lectures from behind a curtain.

\section{ApPENDIX}

The individual human capital index $q_{i}$ of an individual $i$ is given by:

$$
\begin{aligned}
q_{i}= & -1.76+0.43 \ln (\mathrm{nb} . \text { characters of the longest Wikipedia page }) \\
& +0.40 \ln (\mathrm{nb} \text {. wikipedia pages in different languages })+0.47 \ln (\text { nb. works in Worldcat }) \\
& +0.46 \ln (\mathrm{nb} \text {. publication languages in Worldcat })+0.47 \ln (\mathrm{nb} \text {. library holdings in Worldcat })
\end{aligned}
$$

We assume that having no Wikipedia page is similar to having one page with a length of 60 characters and that having no Worldcat page is similar to having a page with one work in one language held by one library. The constant -1.76 normalizes $q_{i}$ at 0 when there is neither a Wikipedia page, nor a Worldcat page. The weights $(0.43,0.40$, etc) are obtained from the first principal component of the five indicators (De la Croix et al. 2020).

The notability $Q$ of a university aggregates the $q$ of the top 5 persons who were active in the preceding 25 years using the following formula:

$$
Q=\sqrt{\sum_{i=1}^{5} \frac{1}{5}\left(\frac{q_{i}}{s_{i}}\right)^{2}}
$$

where $s_{i}$ is the number of universities in which $i$ had an appointment. 


\section{ACKNOWLEDGMENTS}

This project has received funding from the European Research Council (ERC) under the European Union's Horizon 2020 research and innovation programme under grant agreement No 883033 "Did elite human capital trigger the rise of the West? Insights from a new database of European scholars." We thank David Gentilcore for comments on an earlier draft.

First version December 3, 2020. Updated September 4, 2021

\section{REFERENCES}

Bernabeo, Raffaele A., and Giuseppe D’Antuono. 1988. La scuola medica di Bologna. Settecento anni di storia. Bologna: Firma Libri.

Blasutto, Fabio, and David De la Croix. 2021. "Catholic Censorship and the Demise of Knowledge Production in Early Modern Italy." CEPR Discussion Paper 16409.

Calcaterra, Carlo. 1948. Alma mater Studiorum. L'università di Bologna nella storia della cultura e della civiltà. Bologna: Zanichelli.

Cevoloni, Enrico, and Giulia Buscaroli. 2018. "Dispute sulla terica tra gli speziali e Ulisse Aldrovandi nella Bologna del XVI secolo." Atti e Memorie. Rivista di Storia della Farmacia., April, 39-50.

De la Croix, David, Frédéric Docquier, Alice Fabre, and Robert Stelter. 2020. "The Academic Market and the Rise of Universities in Medieval and Early Modern Europe (1000-1800)." CEPR Discussion Paper 14509.

De la Croix, David, and Marc Goñi. 2020. "Nepotism vs. Intergenerational Transmission of Human Capital in Academia (1088-1800).” CEPR Discussion Paper No. 15159.

De la Croix, David, and Pauline Morault. 2020. "Winners and Losers from the Protestant Reformation: An Analysis of the Network of European Universities." UCLouvain.

De Bujanda, Jésus Martínez, and Marcella Richter. 2002. Index des livres interdits: Index librorum prohibitorum. Montréal: Médiaspaul.

Grendler, Paul F. 2002. The universities of the Italian Renaissance. Baltimore: JHU Press.

Istituto dell'Enciclopedia Italiana. 1929. Treccani. Enciclopedia Italiana di scienze, lettere ed arti. Roma: Istituto dell'Enciclopedia Italiana. Also available at https://www.treccani.it/.

. 1961. Treccani. Dizionario Biografico degli italiani. Roma: Istituto dell'Enciclopedia Italiana. Also available at https://www.treccani.it/.

Mazzetti, Serafino. 1847. Repertorio di tutti i Professori antichi e moderni della famosa Università, $e$ del celebre Istituto delle Scienze di Bologna. Bologna: tipografia di San Tommaso d'Aquino.

Prudhomme, Louis Marie. 1830. Biographie universelle et historique des femmes célèbres mortes ou vivantes. Paris: Libraire Lebigre.

Rashdall, Hastings. 1895. The Universities of Europe in the Middle Ages. Oxford: Clarendon Press.

Sorbelli, Albano, and Luigi Simeoni. 1940. Storia dell'Università di Bologna. Volume I, Il Medioevo (secoli XI-XV), Volume II, L'età moderna (1500-1888). Bologna: chelli.

Stelter, Robert, David De la Croix, and Mikko Myrskylä. 2021. "Leaders and Laggards in Life Expectancy among European Scholars from the Sixteenth to the Early Twentieth Century." Demography 58:111-135.

Taisand, Pierre. 1721. Les vies des plus celebres jurisconsultes de toutes les nations, tant anciens que modernes, savoir, latins ou romains, francois, espagnols, italiens, allemans, anglois, hollandois. Paris: Sevestre. 